\title{
Influência da temperatura e do tempo de armazenamento nas dosagens bioquímicas de uréia e creatinina em soro ou plasma caninos
}

[Effect of temperature and storage time on urea and creatinine dosages from canine serum or plasma]

\author{
S.T. Fernandes ${ }^{1}$, M.N. Teixeira ${ }^{2}$, E.S. Santos ${ }^{3}$ \\ ${ }^{1}$ Bolsista Pibic/CNPq - Departamento de Medicina Veterinária - UFRPe \\ ${ }^{2}$ Departamento de Medicina Veterinária - UFRPe \\ Rua D. Manoel de Medeiros, s/n, Recife, PE \\ ${ }^{3}$ Departamento de Física e Matemática - UFRPe
}

Recebido para publicação em 10 de novembro de 2000.

*Autor para correspondência

E-mail: miriam_teixeira@uol.com.br

\section{RESUMO}

O trabalho teve como objetivos avaliar algumas condições de estocagem de soro e de plasma com EDTA $10 \%$ utilizados para determinação dos valores de uréia e creatinina em cães, e avaliar a possibilidade de substituir o soro pelo plasma conservado com EDTA 10\%. Foram realizadas 3600 análises (1800 amostras de soro e 1800 de plasma) com amostras que permaneceram em temperaturas ambiente, de refrigeração e de congelamento. As análises foram realizadas imediatamente após a obtenção da amostra (tempo 0) e após 2, 6, 12, 24, 72 horas e 30 e 60 dias após a coleta do sangue. Os resultados permitiram concluir que a uréia conservou-se por mais tempo na amostra sérica refrigerada até 30 dias e a creatinina na amostra sérica congelada até $72 \mathrm{~h}$. O soro mostrou mais estabilidade que o plasma em todas as condições de estoque estabelecidas.

Palavras-chave: Cão, uréia, creatinina, conservação

\begin{abstract}
Aiming to evaluating some conditions of EDTA $10 \%$ serum and plasma storage for urea and creatinine values determinations in canines as well as analyzing the possibility of serum substitution by plasma, a total of 3600 samples (1800 serum and 1800 of plasma) were analyzed at room, refrigeration and freezing temperatures. Different time intervals were used in the analysis: immediately after sampling (time 0), and at 2, 6, 12, 24, and 72 hours, and 30 and 60 days after the blood collection. The data showed that urea remains conserved for more time in the refrigerated serum sample until 30 days and the creatinine in the frozen serum sample until 72 hours. Serum showed more stability than plasma in all storage conditions established.
\end{abstract}

Keywords: Dog, urea, creatinine, conservation

\section{INTRODUÇ̃̃O}

Entre as provas de rotina utilizadas na avaliação da função renal destacam-se as dosagens de uréia e de creatinina. A uréia é sintetizada no fígado e seu ciclo incorpora duas moléculas de amônia cuja principal fonte provem do catabolismo protéico (Finco, 1997). A dosagem deve ser realizada sempre que houver suspeita de redução do funcionamento renal (Coles, 1984). A creatinina é uma substância nitrogenada não proteíca. Tecidos musculares contém fosfocreatina que sofre ciclização espontânea formando creatinina 


\section{Fernandes et al.}

(Finco, 1997). A creatinina é excretada pela filtração glomerular e qualquer anormalidade que diminua a velocidade do fluxo urinário irá resultar na elevação da concentração sérica (Coles, 1984).

Na dosagem de creatinina em cães, Thoresen et al. (1992) relataram instabilidade em soro e plasma heparinizado quando armazenado com o coágulo e estabilidade por três dias sem o coágulo à $4^{\circ} \mathrm{C} \mathrm{e} 20^{\circ} \mathrm{C}$, enquanto Thoresen et al. (1995) relataram instabilidade durante o período de estocagem do soro e do plasma heparinizado em 90 e 240 dias, sob condições de temperatura de $-20^{\circ} \mathrm{C}$ e $-70^{\circ} \mathrm{C}$. Doretto (1996) verificou estabilidade sérica em bovinos por 30 dias à $25^{\circ} \mathrm{C}$ e por 90 dias quando estocados à $5^{\circ} \mathrm{C}$ e $-20^{\circ} \mathrm{C}$. Ahsan et al. (1995) observaram estabilidade por seis dias à $23-25^{\circ} \mathrm{C}$ e por sete dias à $4-5^{\circ} \mathrm{C}$ em soro de camelos. A metodologia aplicada pelos autores citados foi a da reação de Jaffé, exceto Doretto (1996), que utilizou o método de Lustosa-Basques. Os laboratórios Labtest, Analisa e Doles concordam quanto ao tempo e temperatura de conservação da amostra sérica por sete dias entre 2 e $8^{\circ} \mathrm{C}$ (Analisa, 1995; Labtest, 1995).

$\mathrm{Na}$ avaliação da uréia, Wittwer et al. (1986) apontaram estabilidade sérica em bovinos à $4^{\circ} \mathrm{C}$ e $20^{\circ} \mathrm{C}$ por 72 horas e $-25^{\circ} \mathrm{C}$ por um ano com coágulo. Doretto (1996) observou estabilidade nos níveis séricos por cinco dias à $25^{\circ} \mathrm{C}$ e por 90 dias à $5^{\circ} \mathrm{C}$ e $-20^{\circ} \mathrm{C}$ em bovinos. Em eqüinos, Lindner (1991) relatou instabilidade em temperaturas ambiente e de refrigeração. Thoresen et al. (1992) indicaram estabilidade quando conservados com ou sem coágulo por três dias à $4^{\circ} \mathrm{C}$ e $20^{\circ} \mathrm{C}$ em cães, e Thoresen et al. (1995) informaram que a uréia, nessa espécie, sofre alterações quando acondicionadas por 90 e 240 dias à temperatura de $-20^{\circ} \mathrm{C}$ e $-70^{\circ} \mathrm{C}$. Ahsan et al. (1995) declararam que a atividade sérica em camelos é estável por quatro dias à $23-25^{\circ} \mathrm{C}$ e por oito dias à $4-5^{\circ} \mathrm{C}$. O método da urease foi empregado por todos os autores citados, exceto Doretto (1996) que aplicou o método do diacetil modificado.

Fatores relacionados à metodologia e à amostra utilizada, além da espécie animal podem influenciar nas condições ideais de conservação da amostra (Davy et al., 1984). Desse modo, este trabalho teve como objetivos testar a disponibilidade do plasma com EDTA $10 \%$ como substituto satisfatório do soro e avaliar as melhores condições de armazenamento dessas amostras nas dosagens de uréia e creatinina em cães.

\section{MATERIAL E MÉTODOS}

Foram utilizados cinco cães adultos jovens, sem raça definida, de ambos os sexos e clinicamente sadios, que permaneceram alojados no canil de pesquisas do Departamento de Medicina Veterinária (DMV) da Universidade Federal Rural de Pernambuco (UFRPE). Amostras de sangue foram coletadas sempre pela manhã, com os animais em jejum de 12 horas. Colhidas por punção da veia braquio-cefálica as amostras foram envasadas em dois tubos de vacuntainer, um deles com a solução anticoagulante etilenodiamenotetracetato de sódio (EDTA) a $10 \%$ e o outro sem. Durante a coleta foram realizados os procedimentos rotineiros de tricotomia e antissepsia do local com álcool iodado.

Após separação, o soro e o plasma obtidos foram envasados em frascos de vidro estéreis identificados. As amostras foram então agrupadas: A1 - amostras de soro conservadas em temperatura ambiente ( 25 a $\left.28^{\circ} \mathrm{C}\right)$, A2 - amostras de plasma conservadas em temperatura ambiente $\left(25\right.$ a $\left.28^{\circ} \mathrm{C}\right)$, esses dois grupos analisados imediatamente após a obtenção da amostra (tempo 0) e nos tempos de 2, 6, 12 e 24 horas após a coleta; B1 - amostras de soro conservadas sob refrigeração $\left(4\right.$ a $\left.8^{\circ} \mathrm{C}\right), \mathrm{B} 2$ - amostras de plasma conservadas sob refrigeração $\left(4\right.$ a $\left.8^{\circ} \mathrm{C}\right)$, os dois grupos avaliados nos tempos de $6,12,24,72$ e 720 horas (30 dias) após a coleta; $\mathrm{C} 1$ - amostras de soro conservadas sob congelamento $\left(-20^{\circ} \mathrm{C}\right)$ e $\mathrm{C} 2$ - amostras de plasma conservadas sob congelamento $\left(-20^{\circ} \mathrm{C}\right)$ analisadas nos tempos de $12,24,72,720$ e 1440 horas $(60$ dias) após a coleta. Foram realizadas seis repetições por animal totalizando 30 amostras de soro e 30 de plasma analisadas em cada tempo estabelecido nos devidos grupos. Utilizaram-se kits comerciais (LABTEST - Sistema Diagnóstico Ltda. Lagoa Santa, MG) seguindo a metodologia de Lustosa-Basques para a 
Influência da temperatura e do tempo de armazenamento nas dosagens bioquímicas...

dosagem de creatinina e o método da urease para a dosagem da uréia. As leituras foram realizadas em fotocolorímetro ${ }^{1}$.

Os dados foram analisados com auxílio do programa computacional SAS, utilizando-se o tempo 0 como controle. Foram realizadas análises de variância para os diferentes tempos em cada grupo e em seguida foi aplicado o teste de Turkey para comparação das médias.

\section{RESULTADOS}

Ocorreram alterações significativas nas amostras quando submetidas a certas condições de armazenamento. Quandomantidas na temperatura ambiente (Tab. 1) ou sob refrigeração (Tab. 2), as amostras séricas de uréia não mostraram alterações significativas em nenhum dos tempos pesquisados. Porém as amostras plasmáticas apresentaram alterações significativas $6 \mathrm{~h}$ e $72 \mathrm{~h}$ após a primeira análise, quando submetidas à refrigeração e congelamento, respectivamente. Quando congeladas (Tab. 3), as amostras séricas apresentaram alterações significativas aos 60 dias após a primeira análise, enquanto que nas amostras plasmáticas observaram-se oscilações significativas em todos os tempos estudados, exceto nas $72 \mathrm{~h}$.

Quanto à creatinina, as amostras séricas quando conservadas à temperatura ambiente não apresentaram alterações significativas nos tempos estudados, porém as amostras plasmáticas mostraram alteração a partir de $2 \mathrm{~h}$ após a primeira análise. Quando refrigerada nenhuma alteração significativa foi observada até 24h após a primeira análise quando se utilizaram amostras de soro, porém quando este foi substituído pelo plasma, alterações ocorreram a partir de $12 \mathrm{~h}$. Sob congelamento, as avaliações séricas da creatinina foram diferentes do tempo 0 de análise a partir de 30 dias, enquanto que nas amostras plasmáticas as alterações significativas ocorreram a partir das $12 \mathrm{~h}$.

Tabela 1. Valores de uréia e creatinina no plasma conservado com EDTA $10 \%$ e no soro sangüíneo mantidos à temperatura ambiente $\left(25^{\circ} \mathrm{C}\right)$, nos diferentes tempos de avaliação

\begin{tabular}{ccccc}
\hline \multirow{2}{*}{ Tempo (horas) } & \multicolumn{2}{c}{ Uréia (mg/dl) } & \multicolumn{2}{c}{ Creatinina $(\mathrm{mg} / \mathrm{dl})$} \\
\cline { 2 - 5 } & Sérica & Plasmática & Sérica & Plasmática \\
\hline 0 & $44,28 \mathrm{a}^{*}$ & $40,27 \mathrm{a}^{*}$ & $1,05 \mathrm{a}^{*}$ & $1,16 \mathrm{a}^{*}$ \\
2 & $43,27 \mathrm{a}$ & $39,65 \mathrm{a}$ & $1,05 \mathrm{a}$ & $1,04 \mathrm{~b}$ \\
6 & $40,91 \mathrm{a}$ & $37,24 \mathrm{~b}$ & $1,04 \mathrm{a}$ & $0,91 \mathrm{~b}$ \\
12 & $40,23 \mathrm{a}$ & $34,34 \mathrm{~b}$ & $0,90 \mathrm{a}$ & $0,66 \mathrm{~b}$ \\
24 & $37,51 \mathrm{a}$ & $31,25 \mathrm{~b}$ & $0,93 \mathrm{a}$ & $0,44 \mathrm{~b}$ \\
\hline
\end{tabular}

Tabela 2. Valores da uréia e creatinina no plasma conservado com EDTA $10 \%$ e no soro sangüíneo mantidos sob refrigeração $\left(2\right.$ a $\left.8^{\circ} \mathrm{C}\right)$, nos diferentes tempos de avaliação

\begin{tabular}{ccccc}
\hline \multirow{2}{*}{ Tempo (horas) } & \multicolumn{2}{c}{ Uréia $(\mathrm{mg} / \mathrm{dl})$} & \multicolumn{2}{c}{ Creatinina $(\mathrm{mg} / \mathrm{dl})$} \\
\cline { 2 - 5 } & Sérica & Plasmática & Sérica & Plasmática \\
\hline 0 & $44,28 \mathrm{a}^{*}$ & $39,70 \mathrm{a}^{*}$ & $1,05 \mathrm{a}^{*}$ & $1,17 \mathrm{a}^{*}$ \\
6 & $42,11 \mathrm{a}$ & $42,40 \mathrm{a}$ & $1,06 \mathrm{a}$ & $1,16 \mathrm{a}$ \\
12 & $40,09 \mathrm{a}$ & $41,15 \mathrm{a}$ & $0,90 \mathrm{a}$ & $1,05 \mathrm{~b}$ \\
24 & $37,88 \mathrm{a}$ & $39,06 \mathrm{a}$ & $0,98 \mathrm{a}$ & $0,81 \mathrm{~b}$ \\
72 & $38,28 \mathrm{a}$ & $34,84 \mathrm{~b}$ & $0,79 \mathrm{~b}$ & $0,68 \mathrm{~b}$ \\
720 & $41,13 \mathrm{a}$ & $29,04 \mathrm{~b}$ & $0,69 \mathrm{~b}$ & $0,62 \mathrm{~b}$ \\
\hline
\end{tabular}

*Médias seguidas pela mesma letra na coluna não apresentam diferenças entre si $(\mathrm{P} \leq 0,05)$.

${ }^{1}$ Analyser - 500s - São Paulo, SP 


\section{Fernandes et al.}

Tabela 3. Valores da uréia e creatinina no plasma conservado com EDTA $10 \%$ e no soro sangǘneo mantidos sob congelamento $\left(-20^{\circ} \mathrm{C}\right)$, nos diferentes tempos de avaliação

\begin{tabular}{ccccc}
\multirow{2}{*}{ Tempo (horas) } & \multicolumn{2}{c}{ Uréia $(\mathrm{mg} / \mathrm{dl})$} & \multicolumn{2}{c}{ Creatinina $(\mathrm{mg} / \mathrm{dl})$} \\
\cline { 2 - 5 } & Sérica & Plasmática & Sérica & Plasmática \\
\hline 0 & $44,28 \mathrm{a}$ & $40,28 \mathrm{a} *$ & $1,06 \mathrm{a}$ & $1,61 \mathrm{a}$ \\
12 & $48,39 \mathrm{a}$ & $45,91 \mathrm{~b}$ & $1,16 \mathrm{a}$ & $0,89 \mathrm{~b}$ \\
24 & $44,81 \mathrm{a}$ & $43,25 \mathrm{~b}$ & $1,07 \mathrm{a}$ & $0,75 \mathrm{~b}$ \\
72 & $40,32 \mathrm{a}$ & $40,88 \mathrm{a}$ & $0,90 \mathrm{a}$ & $0,52 \mathrm{~b}$ \\
720 & $37,20 \mathrm{a}$ & $37,12 \mathrm{~b}$ & $0,62 \mathrm{~b}$ & $0,32 \mathrm{~b}$ \\
1440 & $33,092 \mathrm{~b}$ & $33,04 \mathrm{~b}$ & $0,28 \mathrm{~b}$ & $0,15 \mathrm{~b}$ \\
\hline
\end{tabular}

\section{DISCUSSÃO}

Os dados obtidos nas avaliações de laboratório da uréia revelaram que o soro parece conservar-se por mais tempo que o plasma com EDTA 10\% nas diferentes temperaturas estudadas, caracterizando grande flexibilidade na conservação deste para dosagens de uréia, desde que respeitadas as condições de coleta e utilização de material estéril. Quando mantidas na temperatura ambiente ou sob refrigeração, as amostras séricas não apresentaram alterações significativas em nenhum dos tempos pesquisados, ou seja as amostras poderão ser analisadas até $24 \mathrm{~h}$ ou mais, quando em temperatura ambiente $\left(25^{\circ} \mathrm{C}\right)$ ou por 30 dias ou mais na temperatura entre 2 e $8^{\circ} \mathrm{C}$. Alguns autores observaram flexibilidade ainda maior nessas análises em diferentes espécies como Ahsan et al. (1995), em camelos e Doretto (1996), em bovinos. Thorensen et al. (1992) relataram até três dias na temperatura de 4 a $20^{\circ} \mathrm{C}$ em soro de cães, salientando que a presença do coágulo não alterou os resultados. Quando congelada à $-20^{\circ} \mathrm{C}$, as amostras séricas mostraram alterações significativas somente nas 1440h (60 dias), enquanto Wittwer et al. (1986) observaram estabilidade de até um ano em amostras séricas de bovinos com e sem coágulo, estocadas à temperatura de $-25^{\circ} \mathrm{C}$. Thorensen et al. (1995) e Doretto (1996) observaram maior flexibilidade na mesma temperatura, até os 90 dias, trabalhando com amostras séricas de cães e bovinos, respectivamente. Nas amostras plasmáticas conservadas com EDTA $10 \%$, alterações ocorreram logo nas primeiras $6 \mathrm{~h}$ e $72 \mathrm{~h}$, quando mantidas sob temperatura ambiente e de refrigeração, respectivamente. Quando congelada à $20^{\circ} \mathrm{C}$, observou-se que as amostras plasmáticas apresentaram alterações em todos os tempos estudados, exceto nas 72h. Essas oscilações associadas ao fato de nenhum dos autores pesquisados terem utilizado a mesma amostra na dosagem da uréia sugerem condenar o uso desta para análises em cães, desde que não seja feita imediatamente após a coleta, apesar de alguns fabricantes de kits comerciais admitirem a utilização dessa amostra, atestando sua estabilidade até $12 \mathrm{~h}$ entre 15 e $25^{\circ} \mathrm{C}$ e até vários dias entre 2 e $8^{\circ} \mathrm{C}$ (Analisa, 1995; Labtest, 1995). Tal fato pode estar relacionado à recomendação para uso humano. Quanto à técnica, todos os autores citados utilizaram o mesmo procedimento desta pesquisa, exceto Doretto (1996).

Quanto à creatinina, os resultados também mostraram maior estabilidade das amostras séricas do que das plasmáticas nos diferentes grupos. Na temperatura ambiente ou na refrigerada amostras séricas foram estáveis até 24h. Doretto (1996) e Ahsan et al. (1995) observaram estabilidade por mais tempo, 30 dias à $25^{\circ} \mathrm{C}$, e seis dias entre 23 e $25^{\circ} \mathrm{C}$, respectivamente, e 90 dias entre 5 e $-20^{\circ} \mathrm{C}$ e sete dias entre 4 e $5^{\circ} \mathrm{C}$, respectivamente. O primeiro trabalhou com bovinos e o segundo com camelos. Thorensen et al.(1992) observaram estabilidade de três dias em amostras conservadas entre 4 e $20^{\circ} \mathrm{C}$. Sob congelamento as amostras séricas apresentaram menor estabilidade do que a observada por Doretto (1996), igual a 90 dias. Avaliações plasmáticas foram feitas por Thorensen et al. (1995), porém utilizando o plasma heparinizado, os quais demonstraram instabilidade aos 240 dias nas condições de congelamento à $-20 \mathrm{e}-70^{\circ} \mathrm{C}$.

Para dosagem de uréia e creatinina devem ser utilizadas amostras séricas preferencialmente às plasmáticas contendo EDTA 10\%. Os dados alertam para a necessidade de padronizar as condições de conservação das amostras, adequadas às de trabalho de cada laboratório, pois diferenças significativas 
Influência da temperatura e do tempo de armazenamento nas dosagens bioquímicas...

foram observadas entre este trabalho e o de outros autores. Parece que fatores relacionados às condições de execução dos testes são mais determinantes do que as variações entre as espécies.

\section{REFERÊNCIAS BIBLIOGRÁFICAS}

ANALISA: Sistema para diagnóstico. Belo Horizonte, MG, 1995.

AHSAN, S., AFZAL, M., AKHTAR, S. Effect of storage on some constituents of camel serum. Austr. Vet. J., v.72, p.212-215, 1995.

COLES, E.H. Patologia clínica veterinária. 3.ed. São Paulo: Editora Manole Ltda., 1984.

DAVY, C.W., JACKSON, M.R., WALKER, J.M. Stabilities of some constituents of marmoset (Callithrix jacchus) plasma under various conditions of storage. Clin. Chem., v.30, p.101-104, 1984.

DORETTO, J.S. Influência do tempo e da temperatura de estocagem sobre a estabilidade de alguns constituintes do soro sangüineo de bovinos. Jaboticabal: Faculdade de Ciências Agrárias Veterinárias da UNESP, 1996. 61p. (Dissertação, Mestrado)

FINCO, D.R. Kidney function. In: KANEKO, J.J., HARVEY, J.W., BRUSS, M.L. Clinical biochemistry of domestic animals. 5.ed. New York: Academic Press, 1997. Cap. 17, p. 441-484

LABTEST: Sistemas para diagnósticos. Lagoa Santa, MG, 1995

LINDNER, A. Einflub von lagerungsdauer, temperatur und probenausgangsmaterial auf klinish-chemische blutearrablen. J. Vet. Med. Assoc., v.38, p.433-440, 1991.

THORESEN, S. I., HAVRE, G. N., MORBERG, H. et al. Effects of storage time on chemistry results from canine whole blood, heparinized whole blood, serum and heparinized plasma. Vet. Clin. Pathol., v. 21, p. 88-94, 1992.

THORESEN, S. I., TVERDAL, A., HAVRE, G. et al. Effects of storage time and freezing temperature on clinical chemical parameters from canine serum and heparinized plasma. Vet. Clin. Pathol., v. 24, p. 129-133, 1995.

WITTWER, F., BOHNWALD, H., KLAASEN, R. Efecto del tiempo, temperatura de conservacion y del anticoagulante (EDTA/NaF) en muestras para perfiles metabolicos. Arch. Med. Vet., v. 18, p. 43-51, 1986. 